\title{
The Analysis of Characters' Speech Acts in Hills Like White Elephants
}

\author{
Ren Jiahong
}

\begin{abstract}
Hills Like White Elephants is a famous classic novel written by Ernest Miller Hemingway in 1927. The novel is extremely short, only 1455 words. The most important character of the novel is that the short story reveals figures' spirits in the form of daily dialogues. Therefore, this article intends to study the conversations and behaviors from the perspective of Speech Act Theory to explore how the writer portrayed the two typical characters. Speech Act Theory is an important theory in the study field of pragmatics, which was proposed by Austin in 1955 and then was developed by Searle. Therefore, this article will analyze Hemingway's short novel Hills Like White Elephants from speech act theory perspective, such as from it's speech and acts. Thus we will have a better understanding about the characters' relationship in the novel and the author's purposes in writing this novel. And the author's writing features will be reproduced, as well as the topic of the novel, the way of the language expressions and the relation of the significance. Above all, we can see that Speech Act Theory plays an important role in analyzing utterances in the novel. The analysis of the speech acts of the characters in Hills Like White Elephants can not only help people understand this novel but also provide materials to study this classical novel in new field. It is also hoped that the analysis of Hills Like White Elephants will arouse an important way to the appreciation of other classical novels.
\end{abstract}

Key Words: Speech Act Theory; Speech Acts; Hills Like White Elephants; Utterance analysis

\section{INTRODUCTION}

Ernest Miller Hemingway(1899-1961) is a distinctive writer in America and he is good at writing dialogues. His another feature is "Iceberg Principle", which he firstly introduced in his work Death in the Afternoon. In the novel the "Iceberg Principle" means the distinctive images are produced by using brief words and there are hidden feelings and thoughts of the author. Although the readers can not get the meaning in a direct way, they can also feel deeply what the author wants to express.

His novel is a famous classic novel written in 1927 and now is part of "Men Without Women". The majority of the novel is dialogues between a girl called Jig and a man who has no clear name waiting a train at a station in Spain. The man tried to persuade the girl to have an abortion all the time, but the girl insistently avoided the topic to talk about the scenery. Therefore the topic became very sensitive. Although the novel is extremely short, only 1455 words, the short story reveals figures' spirits successfully in the form of daily dialogues without any excessive description of psychology, scenes and background knowledge. Besides, symbolism can be seen in the novel.

This article mainly studies the conversations and behaviors from the perspectives of Speech Act Theory to explore how the writer portrayed the two typical characters. The theory of Austin provided a good view for literature study which includes three aspects. Although each act theory is very important in Speech Act Theory, it was easily to be seen that in three function of speech acts, Illocutionary act was the mainly aspect which needed to be studied. Because 
when we analyze a literature work, we usually won't be satisfied only on the literal meaning but to make a clear of the implied meaning of the words. However, the literature work was static and thus there is no too much space for us to analyze the influence produced by a language. Therefore, in this article I will mainly analyze the speech acts of characters from the perspective of illocutionary act theory on the basis of dialogues and behaviors to get the topic of the story, the relationship of the meaning and sense.

\section{THE SPEECH ACT THEORY OF AUSTIN}

The Speech Act Theory was developed by Searle after Austin proposed it in 1950s. And the theory of Austin made people know a new method to study utterances from speech act perspectives and now gradually becomes one of the core contents in modern pragmatics.

In the past, the philosophers mainly studied the description of using language to explain phenomenon. However, Austin connected language with people's acts together. Austin believed that three different acts were performed simultaneously when language was expressed. And these acts could be classified into Locutionary act, Illocutionary act and Perlocutionary act that Austin had proposed in the latter part of his work How to Do Things with Words. And in his view, Locutionary act was used to express some sense, information or thoughts literally. For example, the first sentence "The hills across the valley of the Ebrol were long and white."(Hemingway,1997:29 ) in the novel, the author used this sentence to tell readers the brief background information of the novel literally. Illocutionary act often referred to tell the speaker's purposes of the utterances in the form of asking questions, or giving information. It can be seen as that sometimes people saying one thing means finishing an act. Also in former example, the author used the actual writing act to describe the existed or nonexisted environment. For example, the author used the white color of the hills to do preparations for "white elephant", to make readers associate with the scenery in the novel, and to imply the character's relationship. In a word, the seemly bland words make us know Hemingway's simple writing style and his iceberg principles. Perlocutionary act usually expresses to produce or get some effects of the utterances.

Above all, Austin's Speech Act Theory makes an important sense in the process of language development. And then Speech Act Theory was developed and systemized by his student Searle, who extended his speech act to explain other discourse issues and other significance issues which people paid much attention in their daily life. And his systematic study of speech acts is a major invention to language philosophy and he proposed intentionality theory and discourse theory which make the linguistic study to a new height. And Gradually, the theory was developed by many people from different aspects to analyze the sentence structure.

\section{THE RELATED BACKGROUND OF HILLS LIKE WHITE ELEPHANTS}

\section{The creative background of Hills Like White Elephants}

In A Moveable Feast, it could be seen that Hemingway was too poor to have a good creative environment when he was young, as a result he often went to café in Paris to write something. So that café became an important thing to analyze his writing style. The novel might start to be wrote after he had the talk with a woman who just had an abortion in that café. And Hemingway himself suffered a lot before he married with his second wife because he wanted to forget everything about his first wife and couldn't stand the separation with his second wife. The feeling was just like that the fetus died in his belly which gave ideas to his writing. So the reader might guess the work Hills Like White Elephants was finished during his honeymoon of his second marriage. 


\section{The brief introduction of Hills Like White Elephants}

The novel was extremely short, just 1455 words, the majority of the novel was dialogues about the story of a girl waiting a train with a man who was maybe her boyfriend in one summer at a Spain station. The novel as a kind of fiction text, has it's own syntactic organization, which could express a whole meaning. The whole story was consisted of dialogues with simple words and there was no any extra description so that the readers needed to get the character's feeling and the implied meaning. The dialogue developed gradually until the climax appeared. However, the story ended surprisingly with the problem unsolved. Although the dialogue happened in the public, readers could still feel the nervous atmosphere from the words. At first their conservation was a little bit dull. The girl wanted to ease the embarrassment of the atmosphere, so she said the topic of white elephants. However, the man was out-minded and merely cared about if the girl had the operation. He repeated the topic all the time and the girl became nervous, worried and at last said loudly she would scream. Then the man went to pick up bags and after he came back he asked the girl if she felt better. The girl just said she felt fine. At this time, the story moved towards the climax but suddenly ended without a clear result. The classical ending was different from the surprising ending in the novel of 0 . Henry.

Mialn Kundera thought that the short novel could give readers imagination. So people might guess that the man had been married and forced his lover to have the abortion. Or the man was a bachelor so he didn't want the baby to disturb his quiet life. Or the man cared about the girl and thought that pregnant could make the girl suffer a lot. However, the girl could agreed with the man to have the abortion or not. Kundera's explanation made people have multiple thoughts about the plot of the novel. He took this short story as an example to talk about the art of the novel and he believed it was what had been found in modern novel that using the structure of current time to develop the basis of what our life depended on-the title Hills Like White Elephants related to the character in the novel. There were also other scholars thought the white elephant which implied the girl's pregnant body. However, the metaphor was not so exactly or the association with white elephants was just the girl's unconscious acts.

In the novel , the readers didn't know what kind of life the characters will live, or other thing in their future. But the author seemly didn't care about that at all, only told the story in an objective way just like an onlooker without any his own emotion. His writing style was simple but had rich meaning, and thus this formed the famous Iceberg Theory. In the theory, the author usually used simple words to create distinct images and hided his feelings and emotions deeply under the images so that the reader could get the ideological significance of the novel through the images created before. The novel could also be regarded as an art of ellipsis. Bates believed the ellipsis art of Hemingway was not only an ellipsis of experience but also an ellipsis of thoughts. Although the language was simple, the meaning hidden was rich, which could inspire readers imagination.

Above all, when readers read the novel, they could always feel something unclear hidden in the content. Therefore, maybe it is the reason why we can analyze the content from different aspects.

\footnotetext{
ANALYSIS OF CHARACTERS' SPEECH ACTS IN HILLS LIKE WHITE ELEPHANTS The speech act analysis on the topic of the first surgery

"What should we drink?" the girl asked. She had taken off her hat and put it on the table.

"It's pretty hot," the man said.

"Let's drink beer."

"Dos cervezas," ....

(Hemingway,1997:29)
} 
The dialogue above was firstly proposed by the girl. She asked the American what to drink. In fact, she wanted the man to tell her the name of the drink. And from the acts of the girl "take off her hat" and "put it on the table", the reader might guess why the girl and the man did not say anything each other but just sat by the table silently, which implied the characters' relationship began to change. However, the man just commented on the weather and did not give her the answer. And from the word "should", "we", and "Let's" the reader could imply that the girl loved the man very much. And from the man's words "Dos cervezas", which showed the man was lack of concentration on the girl. Because the word was Spanish, only the man could speak and understand not the girl, and they were in Spain. The girl could not live independently there without the man. Obviously, the man was impatient and gave the irrelevant answer.

The description "looking off at the line of hills."(Hemingway,1997:30) showed that the girl became quietly and now what in her eyes were all the lines of hills, which was an reflection of her bad mood. The man's indifferent words made the girl in desperation. For the man, the girl's efforts were useless. And the words "the line of hills" might imply the meaning of movement and unstableness. Therefore, the girl was whiny at this moment.

And then the girl said the hills were like white elephants. Actually, she expected the man could agree with her words, but the man's reply frustrated her again. Here the hills implied the shape of the big belly of the pregnant. And the elephant meant the fetus. As for the metaphor, the man's answer "I've never seen one."(Hemingway,1997:30) was tit-for-tat and complained. "white elephant" symbolized beauty, expensiveness, rareness and happiness in west. May just because her expectation to fetus, she looked the hills as white elephants. However in the man's eyes, all of these were meaningless and the white elephant was something useless and expensive. In other words, the white elephant was just a heavy burden to the man. So the fetus to him was only an burden.

The sentence "We want two Anis del Toro."(Hemingway,1997:30) told us that the phrase "Anis del Toro" was a kind of liquor, which was harmful to the girl because she had pregnant. And here she did not care about herself at all. It was also can be seen from the latter passage, the girl said she did not care about herself. The man's indifference made her disappointed and she had no choice but only to do that.

"It tastes like licorice...."

"That's the way with everything."

"Yes," said the girl. "Every Thing tastes of licorice...."

"Oh, cut it out."

(Hemingway,1997:30)

The dialogue above showed clearly that when the girl said the word "everything", the reader might guess the "licorice" was not the only thing that the girl wanted to talk about. In fact, the girl did not know what had happened and just replied to the man's question with words, which implied her disappointment and sadness. It included what the girl expected for a long time, and it would lose quickly. The girl had no intention of mentioning the taste of the drink, yet which made the man unhappy and also made the man give an dramatic comments. It can be easily seen that the man ordered the girl stop talking about what made him embarrassed. From the man's words, the reader could know the man was impatient and impolite. He did not care about the girl's words at all. Maybe there were something hidden in his heart. He became angry with the girl, while the girl did not know at all. In contrast, the man's behavior demonstrated that the man was insecure and nervous. Actually, the relationship between lovers should be 
tolerant, however, their relationship was in danger. If we say the man did not understand what the meaning of the metaphor "the hills like white elephants" in the former passage, here the man became to know this disquieting thing. So he started to resist the girl talking about the thing he disliked.

Here "You started it."(Hemingway,1997:30) the word "it" meant a kind of drink, but it became the topic they talked for several times. They might had unpleasant argument and the reader might ask how the girl could be happy. However the girl concealed her feeling habitually. In fact, the girl did not happy at all. Maybe the reason why the girl said she was being amused because she had her own words and thoughts but she was fearful of the man's cold-hearted decision. And she wanted the contradicts with the man to be eased so she made a concession.

In the sentence “...That's all we do, isn't it-look at things and try new drinks?"(Hemingway,1997:30), the word "all" told us that the girl was dislike the vacant and meaningless life. The reader might guess in the past, they just drank, lived at the hotel, and saw the scenery. And from the words of the girl they could see she was trying her best to explore the true meaning of their life. She did not want to live as they had been in the past. She wanted to have a change.

In the sentence "They don't really look like white elephants...."Hemingway,1997:30), the metaphor was mentioned again, but was denied by the girl. She said the hills were not like white elephants and her feelings began to change, which might result from the change of girl's emotion. She did not want to talk about something involved in the abortion. However, her dissimulation was too obvious to hide her worried emotion. The girl tried her best to get the man's attention and made him happy. But the man could not concentrate on the hills, because he just cared about one thing: abortion.

"The beer's nice and cool." The man said.

"It's really an awfully simple operation, Jig...."

“...It's just to let the air in."

(Hemingway,1997:30)

In the sentences above the man said the beer tasted nice which showed the man changed the topic and started to talk about the operation. So what the reader could get was not only that the man tried to persuade the girl to have the abortion but also the man was increasingly in charge. However the girl did not say anything. What was cared about in Jig's brain was not the operation but a series of questions: "what should we do in our future?", "Do you really want me to have the abortion?", "Will you be happy if I take the operation?" and so on. She wanted the man could comfort her, but she knew no matter how much the man said he loved her, she would not happy, because the answer had been in her heart. For the man, the existence of the baby signified more responsibility and obligation, which could not bring him happiness and enjoyment but endless suffering and torment. He wanted the freedom and enjoyment. In fact, in that age, the image of rugged man was just a hopeless pursuit. The man said the operation was simple, however, as we all known, the abortion could make the girl suffer a lot and even in danger. Now that the operation was simple, the girl kept silent, because she was not willing to have the abortion. And then the man omitted the word operation and just used the words "let the air in" to minimize the harm. The man cheated the girl but the girl just kept quiet, which exactly showed the man was very vainglorious and hypocritical.

Besides, the girl's name was Jig. The name was not just a symbol. At first, "Jig" was a kind of dance, which implied the image of the girl. Because the girl was very young and she was a 
wanderer on the face of the earth. And the word "Jig" always occurred in the phrase "Jig is up", which was the meaning of that the game was over. So here we may guess whether their relationship would end because the girl was pregnant or not. Another explanation of the word "Jig" was that it was a special behavior changing according to the change of the environment, which could be proved in the latter passage.

"What makes you think so?"

"That's the only thing that bothers us...."

(Hemingway,1997:30)

The dialogue above told us that at first the man was short-spoken but now the man became garrulous and always found chance to talk with the girl, which reflected the importance of the operation to the man. Although the girl knew the meaning of the man and she did not have the abortion, she started to query to their love.

From the behavior of the girl "The girl looked at the bead curtain, put her hand out and took hold of two of the strings of beads"(Hemingway,1997:30), the reader could feel the anger of the girl, but her love to the man made her have no choice to do but only be silent. And finally the girl decided to have the operation, however the man at this moment started to shirk the responsibility. That is, the operation was the girl's willing not he asked the girl to do the operation.

"And you think the we'll be all right and be happy?"

"I know we will...."

(Hemingway,1997:30)

In the dialogue above, the girl used the word "think", but the man answered the question with the word "know". The man talked about the duty directly, showing his confidence and expectation to comfort and reassure the girl. But the girl was dissatisfied to the man and as if we can see Jig's grimace. However, the man did not consider the girl's feelings and words and talked about the operation all the time. The girl knew the man did not care about her at all, so she used bitter sarcasm to relieve herself.

It can be seen easily from the words “if you don't want to you don't have to."(Hemingway,1997:31) that there was an indirect threat to the girl. In other words, if the girl was unwilling have to have the abortion, their relationship would be influenced and might be separated from each other or even became stranger.

"And if I do you'll be happy and things will be like they were and you'll love me?"

"I love you now...."

“...if I say things are like white elephants, and you'll like it?"

"I'll love it. I love it now but...."

(Hemingway,1997:31)

The words told us that the girl asked the man by using simple future tense, however the man answered by using simple future tense that is the man just mentioned he loved the girl now. He also said "you know" perfunctorily to avoid the girl's question under the circumstance that he was unable to certificate his love to the girl. So he said "love" as an objective truth. From the second answer of the man we can know that the man changed the word "like" to "love" to show his love firmly, but it was opposite to words in the latter sentence, which made the girl realized the man's real intention. From the words of the man above it can be seen clearly that the man 
is a hypocrite. In order to persuade the girl, he said he loved the girl and the baby. So it can be said that he failed to live up to the girl's love. Whether they would be good relationship or not, the reader were not clear. So there was a kind of threat from the words of man. That is, if the girl had the operation, he would love the girl still, or not.

From the words “I won't worry about that because it's perfectly simple."(Hemingway,1997:31), the reader could get that the man was so selfish and indifferent to the girl, which made the girl disillusioned. It also indicated that the man did not deserve the respect and love. Maybe it was a wise way to break off with the man.

\section{The speech act analysis on the topic of the second surgery}

In the words "I don't care about me"(Hemingway,1997:31), the girl started to talked about the operation which showed that she began to accepted the man's idea. And she also knew how to play the "game" with the man. That is, the girl wanted the man's sympathy but the man did not understand. Did the man really care about? Is the girl? In an opposite way, the man did not care about the girl at all.

The sentence "I don't want you to do it if....."(Hemingway,1997:31) showed us that as if the operation was the girl's idea or willing and there was no relation with the man's threat. However, his words precisely exposed his bad intention. And the girl really could not bear for any time. Her action "stood up and walked" reflected her anger. The beautiful scenery what her saw demonstrated her eager to help her out the situation. As if the good days was so far from her.

The description "And we could have all this...."(Hemingway,1997:31) told us that the girl had all the memories in the past. How happy were they! Maybe they had owned the whole world and the man had promised he would make the girl live a happy life. However what else could more easily disappeared that love? her heart had been hurt and she had been tired of the man's answer and explanation. Especially from the word "all", " could", "everything" and " could", which implies she had nothing now and even in future. And in that sentence, the subjective mood was used, which manifested that the girl's desperate attitude and deny to their future.

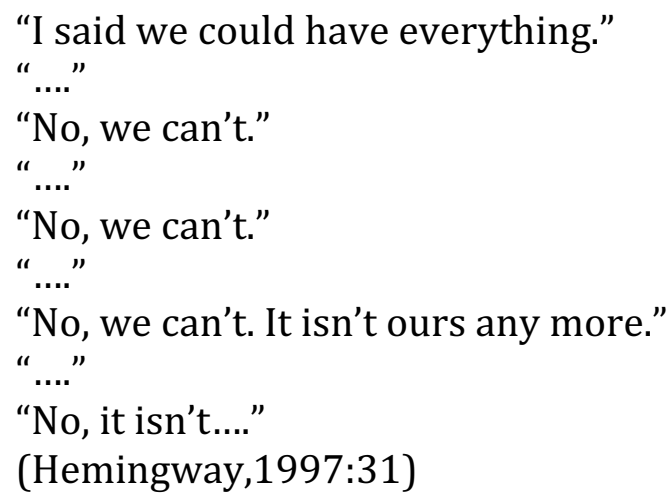

It can be seen from the words above that they could have everything but now all things was so far from them and became impossible. As if the girl had thought about the broken relationship so she had the violent controversy with the man. The girl could not stand this any more. And the four "No" means Jig had her own family values and love concept. Jig believed insistently that family was combination and end-results of the two people who loved each other, as well as the baby was a basis contributed to the stable happiness of the family. There was no doubt that their love would be on the brink of collapse if they did not have a baby. In brief, Jig was very 
clearly that if she had the abortion, their relationship would change, not to mention family and happiness.

"I don't want you to do anything that you don't want to do--"

"...Could we have another beer?"

(Hemingway,1997:32)

The dialogue showed obviously that the man mentioned the operation again. But the girl tried to end up their communication in case of the contradicts.

"All right. But you've got to realize-"

“...Can't we maybe stop talking?"

They sat down at the table and the girl looked across at the hills....

(Hemingway,1997:132)

From the words above the reader can get clearly that after several times debates they had understand the future was so far and the baby was a big burden, which need to be done. Therefore, all words were useless. As if she knew what the man wanted to explain. However she just wanted to be quiet. She wanted the man to talk little, but the man did not understand until the girl said directly. And then their acts showed they were embarrassed sat by the table and did not know what to do.

The words “Doesn't it mean anything to you...."(Hemingway,1997:32) showed when the girl asked the importance of the operation to the man, he pretended and said it was an unimportant thing, which was enough certificated the man was so selfish because he only cared about himself. Although he said he would not ask the girl to do what she was not willing to do, he encouraged the girl have the abortion all the time. And he said what he cared about only was the girl, but it exactly showed what the man cared about was just to have a happy life with the girl rather than undertook any responsibility. As a result, at last the girl saw clearly the man's bad behavior and made her own decision.

\section{The speech act analysis on the topic of the third surgery}

"I'd do anything for you."

"Would you please please please please please please please stop talking?"

"...."

"I'll scream." The girl said.

(Hemingway,1997:32)

From the dialogue above the reader could know easily that in the surface the man was willing to do anything for the girl. And here the seven "please" demonstrated the girl's pain and suffering and showed the girl's maximum tolerance. And how she hated the man just like the volcanic eruption. The dialogue obviously demonstrated their relationship could not be remedied.

The words "She smiled at him."(Hemingway,1997:32) showed clearly that the girl smiled to the man, which certificated that the girl's emotion began to change better. As if the girl had already forgotten the unpleasant moment with the man.

From the description "She...smiled at him."(Hemingway,1997:32), the reader could see clearly that the word "smiled" was opposite with the girl's true feeling, which showed the girl had made her own decision. "I feel fine."(Hemingway,1997:32), the answer was so quiet, which implied the man had hurt the girl deeply. So the reader could make a conclusion that "I feel 
fine" meant what Jig cared about was her own health but what the man really cared about was whether the girl had the operation. The girl said the words repeatedly in order to prevent the man talking about this topic again. And the repeated words also demonstrated she could not show her thoughts clearly to the man. Because of the misunderstanding, she could not express. Jig was a girl who had independent thoughts rather than blindly obedient his boyfriend. She knew she should stand up to be a strong-willed woman. Maybe it was a wise action to leave the man.

\section{CONCLUSION}

The novel is an intriguing short novel and the simple language creates the story successfully. The biggest character of the novel is the white elephant, which symbolizes the baby, as well as the white elephant also implies the lovers' attitude and solution to the problem. For the man, the baby is a big burden and his finally choice is only to enjoy life and to escape from his responsibility which fully tells some characteristics of the lost generation and the influence of the war to people. In the view of the concept of the story, the author tells the story in a direct way, which is showed truly to the reader and leaves more space for the reader to imagine and think deeply. And the author does not comment on the story at all, which attracts more attention of the reader to analyze the novel. Besides, the readers can see easily that in each of his work only one-eighth is on the surface of the water, that is the reader can get the message from the concept directly or easily, while the rest seven-eighths is implicit which means it needs to be understood, that is "Iceberg Principle". Above all, the analysis will contribute us to have a better understanding of their psychological changes.

Obviously, the novel can be said that it is made up by "sound". And from the conversation we can know the illocutionary meaning of the words. That is, their relationship is in an embarrassed period. There are complaining and suffering hidden in their talking and their talk starts from the hills and the drink in the novel. Hemingway uses the unique structure and language to make the content of the story obvious and he just makes the reader feel, guess and imagine the content. Just as the operation, there is no any obvious clue to confirm.

\section{References}

Austin, J. How to Do Things with Words [M]. Oxford: The Clarendon Press. 1962.

Alex Link. Skating everything on it: a stylistic analysis of linguistic patterns in "Hills Like White Elephants" [J]. The Hemingway review. 2004.

Hemingway, E. Men without Women [M]. Scribner: $1^{\text {st }}$ ScribnerPaperback Fiction Ed. 1997.

Hu Zhuanglin. Linguistics: A Course Book<Third Edition>. 北京大学出版社. 2011.

Liu Runqing. Linguistics: A New Coursebook [M]. Foreign Language Teaching and Research Press. 2012.

陈影. 言语之外的叙事--从《白象似的群山》看海明威的文体特征 [J]. 长春教育学院学报. 2008.

米兰·昆德拉. 被背叛的遗嘱 [M]. 余中先译. 上海译文出版社, 2011.

欧内斯特·海明威著《没有女人的男人们》 [M].杨向荣译. 南海出版社 2015 .

唐文俐, 刘汉德. 海明威小说《白象似的群山》中人物对话解读 [J]. 江西社会科学院. 2003.

袁贤铨. 简论海明威的“冰山”风格 [J]. 宁波大学学报: 人文社科版. 1996 